\title{
Volumetric Overload Shocks in the Patho-Etiology of the Transurethral Resection of the Prostate (TURP) Syndrome and Acute Dilution Hyponatraemia: The Clinical Evidence Based on Prospective Clinical Study of 100 Consecutive TURP Patients
}

\author{
Salma A Ghanem ${ }^{1}$, Khalid A Ghanem ${ }^{2}$ and Ahmed N Ghanem ${ }^{3 *}$ \\ ${ }^{1}$ Royal London Hospital, London \\ ${ }^{2}$ Mansoura University Hospital, Egypt \\ ${ }^{3}$ Department of Urology, Egypt
}

*Corresponding author: Ahmed N Ghanem, Retired Consultant Urologist, Egypt

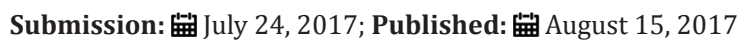

\begin{abstract}
Introduction and objective: Circulatory shock affecting patients with the TURP syndrome has frequently been described, but has usually been mistaken for hypovolaemic blood loss, cardiogenic or septicaemic shock. Here we report a prospective study that proves the patho-aetiology of the TURP syndrome is induced by volumetric overload.

Patients and methods: A prospective study of 100 consecutive patients undergoing TURP was conducted. The volume and type of per- and $24 \mathrm{~h}$ post-operative intravenous fluids infused were recorded and the volumes of glycine absorbed and blood loss were measured. Serum changes in solute contents were also measured before, after and $24 \mathrm{~h}$ after the surgery. Blood and urine cultures were done on all symptomatic patients.

Results: The mean per-operative volume of glycine absorbed, total fluid gained and blood loss were 0.6(SD \pm 0.7$), 1.57( \pm 0.98)$ and $0.356( \pm 0.148)$ litres, respectively. Fifty nine patients absorbed $0-1$ litre, 20 absorbed $1-1.5$ and 12 absorbed $>1.5$ litres of glycine. A total of 20,10 and $4 \%$ of all patients showed a drop in post-operative serum sodium concentration of $>10,>15$ and $>20 \mathrm{mmol} / \mathrm{l}$ respectively. Ten patients fulfilled the criteria of the TURP syndrome manifesting with hypotension shock with bradycardia. Volumetric overload proved to be the only significant factor in causing the TURP syndrome. A significant relationship between the post-operative drop in serum sodium concentration and total volumetric gain of 3.54( \pm 0.6$)$ litres, including IVI fluids, was observed $(\mathrm{P}=0.0001)$. Hypertonic $5 \% \mathrm{NaCl}$ proved effective in treating volumetric overload shocks of the TURP syndrome. Those treated with hypertonic sodium responded promptly and recovered fully passing between 2.5 and 4.5 litres of urine.

Conclusion: The results of this study have shown that the TURP syndrome is precipitated by sodium-free fluid volumetric overload, the result of glycine absorption and intravenously infused fluids. A volume of 3.5 litres induces VOS1. The best treatment for VOS1 of the TURP syndrome is hypertonic $5 \% \mathrm{NaCl}$.

Keywords: Shock; Hyponatraemia; The transurethral resection of the prostate (TURP) syndrome; The adult respiratory distress syndrome (ARDS); Prospective study; Hypertonic sodium

Abbreviations: TURP: The Transurethral Resection of the Prostate; ARDS: The Adult Respiratory Distress Syndrome; HN: Hyponatraemia; VOS: Volumetric Overload Shock; MVOD: The Multiple Vital Organs Dysfunction; SD: Standard Deviation; Hb: Haemoglobin; PCV: Packed Cell Volume; WCC: White Cell Count; IVI: Intravenously Infused
\end{abstract}

\section{Introduction}

The transurethral resection of the prostate (TURP) syndrome is a severe vascular hypotension reaction that complicates endoscopic surgery as a result of massive irrigating fluid absorption causing a drop of serum sodium concentration of $>15 \mathrm{mmol} / \mathrm{l}$ inducing severe acute dilution hyponatraemia $(\mathrm{HN})$ of $<120 \mathrm{mmol} / \mathrm{l}$ [1].
Volumetric Overload Shock (VOS) is a condition caused by massive fluid infusions and is of two types; Type one (VOS1) and Type two (VOS2). VOS1 is induced by sodium-free fluid gain such as $1.5 \%$ Glycine used as irrigating fluid during endoscopic surgery such as the transurethral resection of the prostate (TURP) $[2,3]$. It 
has been reported with other fluids such as Glucose, Mannitol and Sorbitol. It is known as TURP syndrome or HN shock [4] as HN is a marked serological marker for the condition [4,5]. VOS2 is induced by massive infusion of sodium-based fluids such as normal saline, Ringer, Hartmann, plasma and plasma substitutes and/or blood transfusions that may complicate the therapy of VOS1. VOS2 also complicates fluid therapy in critically ill patients suffering from other known shocks such as trauma, hypovolaemic, haemorrhagic and septicaemia shocks and presents with the multiple vital organs dysfunction (MVOD) or failure syndrome. The adult respiratory distress syndrome (ARDS) [6] is another name under which VOS2 is reported. Both VOS1 and VOS2 are complications of fluid therapy. VOS1 has been induced in animals under clean experimental conditions in the absence of haemorrhage and sepsis [7].

The TURP syndrome was first described by Creevy [8] in 1947 as acute water intoxication causing haemolysis, jaundice and acute tubular necrosis. Osmotic solution such as glycine, mannitol and cytal were then introduced but a complex clinical syndrome continued to occur [9]. Hyponatyraemic shock induced by glycine absorption was described by Harrison et al. [4], who introduced 5\% sodium chloride for treatment.

Several authors have measured the volume of glycine absorption [10], the changes in serum sodium and electrolytes [11], sodium loss in urine [12] as well as changes in blood volume, Haemoglobin (Hb) and red cell mass [13]. The syndrome is well described in retrospective studies and individual case reports as bizarre clinical picture which may affect some patients following TURP. The patient may present with coma and paralysis [5,14-17], respiratory distress or arrest [18], renal failure [19] and cardiac dysrythmia or arrest $[20,21]$ and these may occur in any combination.

Circulatory shock affecting patients with the TURP syndrome has frequently been described but has usually been attributed to blood loss [22] cardiogenic [20,21] or septicaemic shock [23]. Erroneous diagnosis may lead to inappropriate treatment with further blood and fluid infusions [24], which may cause death due to brain, myocardial and lung necrosis [25]. Visual loss has also been reported [26]. Post-mortem examination has been documented [25]. The TURS has been attributed to Glycine and ammonia toxicity [27] but it has also been reported with Mannitol $[22,28]$ and Glucose [5].

The discrepancy between the results of prospective trials and the bizarre presentation of the syndrome has given rise to doubts as to its existence and to the theory of ammonia intoxication [27]. However, dilution hyponatraemia, with an incidence of $7 \%$ and $1 \%$ mortality, does occur [29] and a relationship with excessive fluid absorption is now accepted [30].

Professor Hahn et al. reported 480 articles of which $>340$ articles are on the TURP syndrome investigating every aspect of the syndrome confirming the physiological [31-33] and pathological changes reported by other authors [34-37]. Hahn reported on fluid and electrolytes dynamics [38], effect of over-hydration on cardiac muscle [39] and other tissues [40], effect on renal function [41] and compared Glycine to Mannitol. Professor Hahn favoured the toxicity of Glycine as the patho-etiological cause of TURP synbdrome.

Ghanem introduced the concept of volumetric overload in the patho-etiology of TURP syndrome in 1990 [1,2]. He confirmed the effectiveness of hypertonic $5 \% \mathrm{NaCl}$ or $8.4 \%$ Sodium Bicarbonate both as anecdotal evidence [42] and in a prospective study [1,2] and also investigated the underlying faulty physiological law of Starling for the capillary interstitial fluid transfer $[43,44]$. The results of a career life investigation which aimed at quantifying volumetric gain and its relation to the TURP syndrome highlighting VOS are now reported.

\section{Patients and Methods}

A prospective study of 100 consecutive patients undergoing TURP was carried out with the approval o the Medical Ethical Committee. A standard procedure was performed, using an irrigating resectoscope (Stors), 1.5\% glycine irrgant (at a height of $80 \mathrm{~cm}$ above the heart) and suction drainage (Haemonetics Cell Saver IV), which measured blood loss. The absorbed volume of $1.5 \%$ glycine was the difference between volume used and returned. Bumetanide $1 \mathrm{mg}$ was given at the end of the procedure. The volume and type of per- and $24 \mathrm{~h}$ post-operative intravenous fluids infused were recorded. Pre- and post-operative urinary cultures were performed on all patients and blood culture was performed on those showing signs of post-operative circulatory shock.

Blood electrolytes, serum osmolality, glycine, serin and alanine aminoacids were measured on admission to the hospital (A), after anaesthetic induction (B), on termination of the procedure (C) and on the first post-operative morning (D). Further measurements were carried out on symptomatic patients, who were randomised between hypertonic sodium chloride and conservative treatment. Known types of shocks were excluded by quantifying blood loss and doing blood cultures. The osmolality of fluids used in this study were 1.5\% glycine 196, Hartmann's 257, normal saline 287 and 5\% Dextrose $297 \mathrm{mOsm} / \mathrm{kg}$.

\section{Statistical Analysis}

Data were analysed statistically using a computer (Macintosh SE, Apple Computers Ltd) with a commercially available database and statistical packages (Stat View 512, Brain Power inclusive). Patients served as their own controls by a comparison of their pre- and post-operative findings. Data are presented as mean and standard deviation (SD). Student's t-test, multiple regression analysis and x2-tests were used or comparative statistical analysis.

\section{Results}

The mean age of the patients was 74 years (SD \pm 4 ), weight was $70.8 \mathrm{~kg}( \pm 8.6)$, weight of resected prostatic tissue was $30.8 \mathrm{gr}$ $( \pm 21.7)$ and resection time was $56.5 \mathrm{~min}( \pm 27.3)$. The mean volume of $1.5 \%$ glycine used for irrigation per procedure was 16.73 litres $( \pm 10.38)$. The mean per-operative volume of glycine absorbed, total fluid gained and blood loss were $0.6( \pm 0.7), 1.57( \pm 0.98)$ and $0.356( \pm 0.148)$ litres respectively. The mean and SD of volumetric overload of symptomatic patients are show in (Figure 1). 


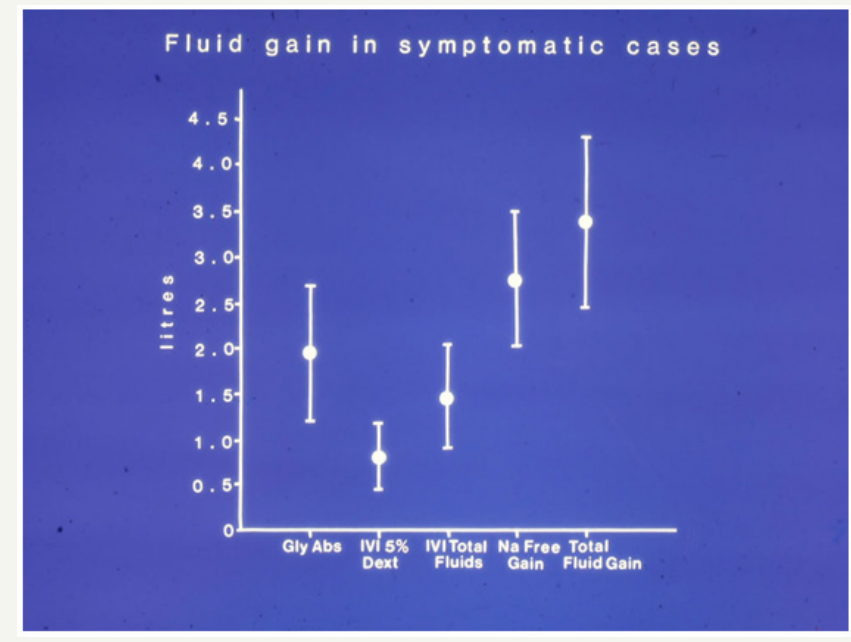

Figure 1: The means and standard deviations in symptomatic patients of Glycine absorbed (Gly abs), intravenously infused 5\% Dextrose (IVI Dext) Total IVI fluids, Total Sodium-free fluid gained (Na Free Gain) and total fluid gain in litres (1).

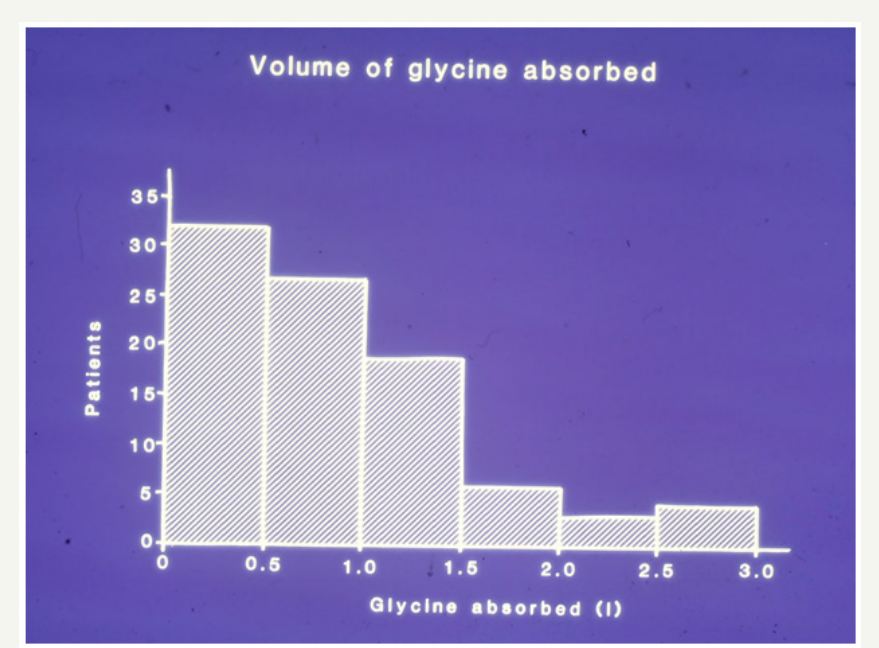

Figure 2: Frequency distribution of patients according to the volume o $1.5 \%$ glycine absorbed. Nine patients who had a negative balance, due to blood and urine loss, are excluded.

The mean $24 \mathrm{~h}$ fluid intake and urine output from the start of surgery were $3.25( \pm 1.557)$ and $4.85( \pm 2.37)$ litres respectively. Ninety three per cent of patients had blood loss $<0.4$ litres, $7 \%$ had blood loss ranging from 0.45 to 1.3 litres. Five patients were retransfused with autologous blood recovered from glycine effluent. Only one of the 15 patients who received blood transfusion had fulfilled the criteria of the TURP syndrome and received one unit of blood: he was thought to have suffered hypovolaemic shock, although his data indicated volume overload (vide infra).

\section{Volume of $1.5 \%$ glycine absorbed}

Figure 2 shows a histogram of the volume of glycine absorbed. Nine patients had a negative fluid balance due to blood and urine loss;
59 patients absorbed 0-1 litre, 20 absorbed 1-1.5 and 12 absorbed $>1.5$ litres. The surgeon's observation on breaching the prostatic capsule and opening of venous sinuses were significantly related to the volume of glycine absorbed and the development of the TURP syndrome $(\mathrm{P}=0.0001)$. These observations were recorded in 11 patients of whom 7 developed the TURP syndrome and 4 did not. A further 3 patients developed the TURP syndrome (vide infra) and in these cases neither perforation of the prostatic capsule nor opening of the venous sinuses was observed by the surgeon. The subjective estimation of bleeding by surgeons and anaesthetists was overestimated by a factor of 3-10 the measured volume of blood loss.

Neither the weight of the resected prostate, resection time nor blood loss reached statistical significance in relation to the volume of glycine absorbed and the development o the TURP syndrome.

\section{Volumetric gain and hyponatraemia}

A total of 20,10 and $4 \%$ of all patients showed a drop in postoperative serum sodium concentration of $>10,>15$ and $>20 \mathrm{mmol} / \mathrm{l}$, respectively. Figure 3 shows a significant relationship between the volume of glycine absorbed and the post-operative changes in serum glycine and sodium concentrations $(\mathrm{P}=0.0001)$. A significant relationship between the post-operative drop in serum sodium concentration and total volumetric gain, including IVI fluids, was also observed $(\mathrm{P}=0.0001)$.

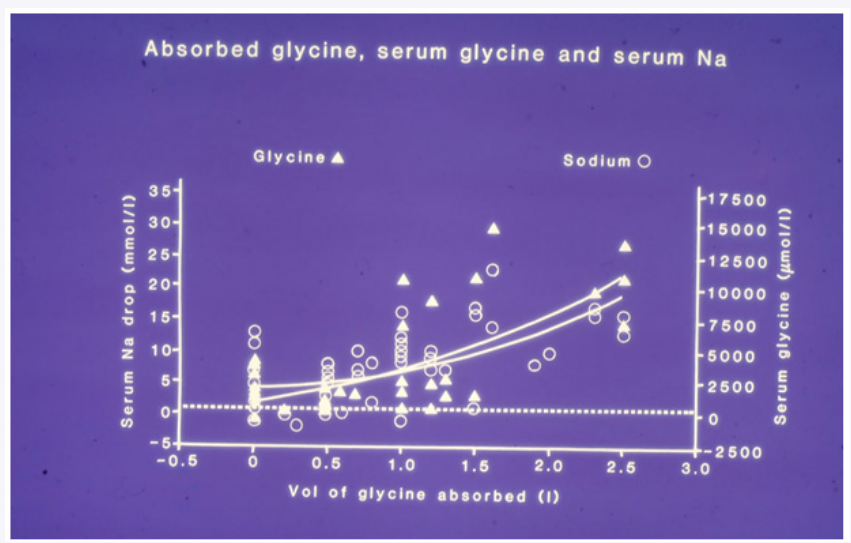

Figure 3: A scatter graph of the 100 patients with curve fits shows relationship of the volume of $1.5 \%$ glycine absorbed to the post-operative serum glycine [Glycine $=3675 \mathrm{X}+658.6$, $\mathrm{R}=0.73, \mathrm{p}=0.0001$, the drop in serum sodium concentration $[\mathrm{O}], \quad[\mathrm{OY}=4.7 \mathrm{X}+3.6, \mathrm{R}=0.7, \mathrm{P}=0.0001]$. The dotted line represents the normal level of serum solute contents (Mean \pm SD).

\section{Serum chemical and haematological changes}

Serum osmolality, chemical and haematological values at the pre-determined times are shown in Table 1. All patients had normal serum osmolality and sodium levels on admission; 3 were hyponatraemic in hospital before surgery, 1 from diuretics, another from steroid therapy and the third had prostatic carcinoma with metastases. 


\section{Post-anaesthetic induction changes}

Comparison of the serum osmolality and solute concentrations after anaesthesia and before the start of surgery with normal value on admission (B vs A using paired t-test) showed a decrease in serum proteins, albumin, calcium, Hb, packed cell volume (PCV) and measured osmolality $(\mathrm{P}=0.0001)$. Serum sodium and white cell count (WCC) also decreased $(\mathrm{t}<0.05)$. The type of anaesthesia was related to the drop in $\mathrm{CO}_{2}$. The patient's weight was related to the drop in serum sodium levels.

\section{Post-surgical changes}

Comparison of the post-surgical with the post-anaesthetic changes (C vs B) revealed a significant drop in serum osmolality, sodium, calcium, proteins, albumin, alkaline phosphatise, $\mathrm{Hb}$ and PCV. Serum glycine, glucose and potassium increased (Table 1). These changes were significant in both symptomatic and asymptomatic patients $(\mathrm{t}=0.0001)$. The drop in serum osmolality was significant in symptomatic cases only $(\mathrm{t}=0.006)$. Table 2 compares the means of symptomatic and asymptomatic patients.
The volume of $1.5 \%$ glycine absorbed, the type and the volume of intravenously infused fluids were significant in relation to the drop in serum osmolality, sodium and protein concentration $(\mathrm{P}=0.001)$. The abnormal rise in serum glucose reaching a level of $11.2(\mathrm{SD} \pm 5.7) \mathrm{mmol} / \mathrm{l}$, was related to the per-operative $5 \%$ Dextrose infusion, and the rise in serum glycine concentration was related to the preoperative volume of the glycine irrigant absorbed $(\mathrm{P}=0.0001)$.

\section{Compensatory $24 \mathrm{~h}$ post-operative changes}

Comparison of the serum changes $24 \mathrm{~h}$ post-operatively with the immediate post-surgical values (D vs C) showed a continuing decrease in serum osmolality $(\mathrm{t}=0.0001)$. Serum sodium, proteins, albumin, calcium, $\mathrm{Hb}, \mathrm{PCV}$ and alkaline phosphatise increased spontaneously, although remaining low, while serum glycine and glucose concentrations decreased $(t=0.0001)$. All returned to normal (Table 1) Serum urea, bilirubin, AST and WCC were significantly raised $(\mathrm{t}=0.05)$.

Table 1: Mean osmolality, chemical and haematological values and Glycine aminoacids.

\begin{tabular}{|c|c|c|c|c|}
\hline Time & $\mathbf{A}$ & B & C & D \\
\hline Osm Measured & 291 & 288 & 286 & 281 \\
\hline Osm calculated & 290 & 288 & 281 & 283 \\
\hline Osm Gap & 1 & 0.3 & 5 & 1 \\
\hline Sodium & 138 & 137 & 132 & 134 \\
\hline Potassium & 4.4 & 4.5 & 4.7 & 4.2 \\
\hline Urea & 7.1 & 7.0 & 7.0 & $7.9^{*}$ \\
\hline Glucose & 6.5 & 6.2 & 11.2 & 8.0 \\
\hline Protein & 65 & 62 & 55 & 58 \\
\hline Albumin & 40 & 38 & 34 & 35 \\
\hline Calcium & 2.27 & 2.16 & 2.04 & 2.11 \\
\hline $\mathrm{CO} 2$ & 28 & 26 & 26 & 27 \\
\hline Bilirubin & 9 & 9 & 9 & 12 \\
\hline AST & 19 & 18 & 18 & 20 \\
\hline Alk Phosphatase & 100 & 100 & $91^{*}$ & 90 \\
\hline $\mathrm{Hb}$ & 13.8 & 13.4 & 12.4 & 12.5 \\
\hline PCV & 0.408 & 0.39 & 0.364 & 0.369 \\
\hline WCC & 9.3 & 8.6 & 8.6 & 11.6 \\
\hline Glycine $(\mu \mathrm{mol} / \mathrm{l})$ & - & 293 & 3599 & 290 \\
\hline Serine & - & 155.6 & $255^{*}$ & 157.5 \\
\hline Alanine & - & $335^{*}$ & $539 *$ & $456.9^{*}$ \\
\hline
\end{tabular}

The values shown in Bold at the immediate (C) and 24h (D) post-operative times are highly significant compared with the pre-operative (B) values $(\mathrm{P}=0.0001$, using paired $\mathrm{t}$ test $)$.

${ }^{*} \mathrm{P}<0.05$

\section{Statistics and symptomatic patients}

The above means and standard deviations (Table 1) and paired t-tests were insensitive in revealing symptomatic patients with the TURP syndrome. Based on pre-defined biochemical and clinical criteria of the syndrome, the results obtained were analysed. A patient who had a drop in serum sodium concentration
$>15 \mathrm{mmol} / \mathrm{l}$, who absorbed more than 1.5 litres of glycine and suffered hypotension, bradycardia or dysrhythmia on ECG tracing with any of the following clinical signs: restlessness, confusion, muscle twitches, circulatory shock, coma, paralysis and respiratory distress, was considered to be suffering from the TURP syndrome. Eight patients fulfilled both the biochemical and clinical criteria 
while 88 patients did not. Two patients despite having a drop of serum sodium of $16 \mathrm{mmol} / \mathrm{l}$, remained asymptomatic, while another 2 patients who showed signs of the syndrome had a drop in serum sodium concentration of only 14 and $13 \mathrm{mmol} / \mathrm{l}$.

\section{The TURP syndrome}

Hypotension associated with bradycardia was a consistent feature of the syndrome and affected 10 patients; initial hypertension occurred in 2 patients only. Episodes of bradycardia on ECG tracing and hypotension occurring during the operation and recovery period were taken from the anaesthetic records and affected 16 patients; 10 had the TURP syndrome with a mean total per-operative volumetric fluid gain of 3.54 litres $(S D \pm 0.6)$. The other 6 patients who had either bradycardia (4) or hypotension (2) in isolation had a mean volumetric gain of 3 litres $( \pm 0.5)$. The remaining 84 patients had a mean total gain of 1.24 litres $( \pm 0.6)$.

Restlessness, confusion and muscle twitches affected all patients; 7 showed signs of circulatory shock with hypotension, coldness, pallor peripheral shut-down and oliguria. Respiratory wheezes and crepitations affected 5 of the symptomatic patients. None suffered cardiac or respiratory arrest and there was no deaths despite a drop in serum sodium concentration of $>20 \mathrm{mmol} / \mathrm{l}$ to a level below $120 \mathrm{mmol} / \mathrm{l}$ in 4 patients, each of whom gained $>3.5$ Litres (Figure 1) and (Table 2).

Table 2: Immediate post-operative means of data comparing symptomatic and asymptomatic patients.

\begin{tabular}{|c|c|c|}
\hline & Symptomatic & Asymptomatic \\
\hline No of Cases & 10 & 90 \\
\hline Glycine absorbed $(1)$ & $\mathbf{1 . 9 4}$ & 0.45 \\
\hline Total fluid gain $(1)$ & $\mathbf{3 . 5}$ & 1.36 \\
\hline Blood loss $(1)$ & 0.321 & 0.36 \\
\hline $\begin{array}{c}\text { Serum Glycine } \\
(\mu \mathrm{mol} / 1)\end{array}$ & $\mathbf{1 0 4 9 9 . 0 0}$ & $\mathbf{1 5 0 8 . 0 0}$ \\
\hline $\begin{array}{c}\text { Serum sodium } \\
\text { drop }\end{array}$ & $\mathbf{1 7 . 7}$ & $\mathbf{4 . 6}$ \\
\hline $\begin{array}{c}\text { Serum osmolality } \\
\text { drop }\end{array}$ & $\mathbf{1 1 . 4}$ & 0.7 \\
\hline
\end{tabular}

Bold figures are significant $(\mathrm{p}<0.05)$. Note that changes in serum glycine and sodium are significant in both symptomatic and asymptomatic cases, while significant change in serum osmolality characterises symptomatic cases only.

The mean post-operative serum sodium concentration of the 10 clinically symptomatic patients was $120.7 \mathrm{mmol}( \pm 3)$. The mean drop in serum sodium was $17.4 \mathrm{mmol} / \mathrm{l}( \pm 4.4)$ and osmolality was $11.4 \mathrm{mOsm} / \mathrm{l}( \pm 8.4)$. The mean volume of glycine absorbed, total fluid gained and blood loss were 1.94, 3.54 and 0.32 litres respectively (Table 2 ).

Multiple regression analysis revealed that a volumetric fluid gain of 3.54 litres $( \pm 0.6)$ was the most consistent statistically significant factor in relation to the clinical signs $(\mathrm{P}=0.0007)$. The drop in serum osmolality was also significant $(\mathrm{P}=0.02)$, but the changes in serum sodium, glycine, albumin, $\mathrm{Hb}$ and calcium did not reach statistical significance (Table 3 ). Serum glycine and sodium changes were significant $(\mathrm{P}=0.003$ and 0.01$)$ when volumetric overload and hypo-osmolality were excluded from the analysis. A volumetric gain of 3.5 litres $( \pm 0.6)$ and a drop in serum osmolality of $11.4 \mathrm{mOsm} / \mathrm{kg}$ characterised patients with the TURP syndrome who all developed VOS1 (Table 2).

Table 3: Multiple regression analysis of total per-operative fluid gain, drop in measured serum osmolality (OsmM), sodium, albumin, $\mathrm{Hb}$ and increase in serum glycine occurring immediately post-operatively in relation to signs of the TURP syndrome. Volumetric gain and hypoosmolality are the only significant factors.

\begin{tabular}{|c|c|c|c|c|c|}
\hline Parameter & Value & Std. Err & $\begin{array}{c}\text { Std. } \\
\text { Value }\end{array}$ & T Value & P \\
\hline Intercept & 0.773 & & & & \\
\hline Fluid Gain (1) & 0.847 & 0.228 & 1.044 & 3.721 & 0.0001 \\
\hline OsmM (C_B) & 0.033 & 00.014 & -0.375 & 2.42 & 0.0212 \\
\hline Na+ (C_B) & 0.095 & 0.049 & 0.616 & 1.95 & 0.0597 \\
\hline Alb (C_B) & 0.062 & 0.087 & 0.239 & 0.713 & 0.4809 \\
\hline Hb (C_B) & -0.282 & 0.246 & -0.368 & 1.149 & 0.2587 \\
\hline Glycine (C_B) & $-4.973 \mathrm{E}-5$ & $5.975 \mathrm{E}-5$ & -0.242 & 0.832 & 0.4112 \\
\hline
\end{tabular}

Multiple regression analysis Y1: postoperative signs $6 \mathrm{X}$ variables. Beta coefficient table

\section{Treatment}

Five of the 10 patients who showed signs of the TURP syndrome were treated with $5 \% \mathrm{NaCl}$ infused at a rate of $200 \mathrm{ml} / 20$ minutes. The other 5 patients plus the 2 patients with asymptomatic drop in serum sodium of $16 \mathrm{mmol} / \mathrm{l}$, were treated conservatively. In the conservatively treated group, 3 patients were given atropine or bradycardia, aminophylline or respiratory distress and a further dose of diuretic (bumetanide $1 \mathrm{mg}$ ). Two patients appeared to suffer hypovolaemic shock despite volumetric overload and they all had the criteria of the TURP syndrome, they were treated with "guarded" volume expansion. The first patient received 1 unit of blood and 1 litre of Haemaccel with bumetanide $2 \mathrm{mg}$, atropine and aminophylline; the second patient received 1.5 litre of Haemaccel, atropine and a further dose of bumetanide. The 2 patients with asymptomatic hyponatraemia were each given a further dose of diuretic. 


\section{Response to treatment}

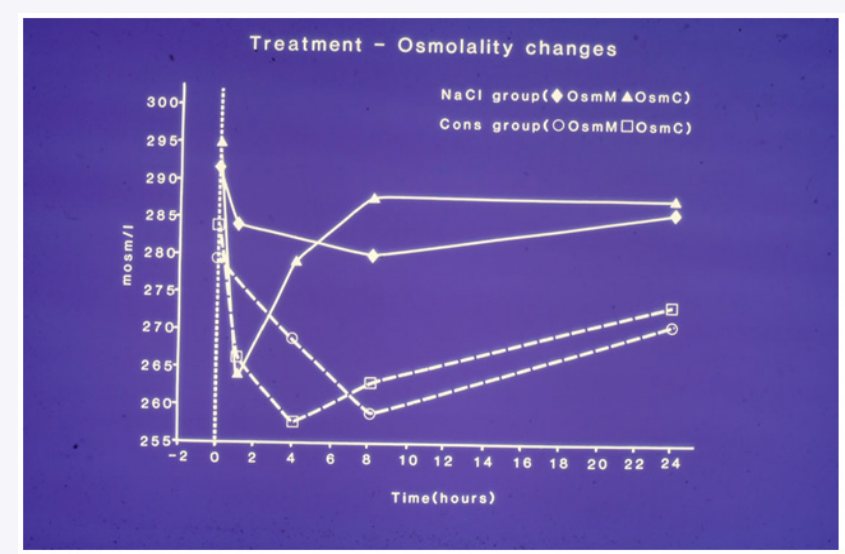

Figure 4: Mean changes in measured serum osmolality (OsmM) and calculated osmolality (OsmC) in patients with the TURP syndrome comparing those infused with $5 \%$ hypertonic sodium (solid lines) and those treated conservatively (slashed lines). OsmC was calculated from the formula $2 \mathrm{xNa}+$ urea+glucose in $\mathrm{mmol} / 1$ of serum concentration [48] thus reflecting changes in serum sodium concentration. The vertical dotted line represents the start of operation (Time B) followed by C, C1, C2 (end of treatment) and $\mathrm{D}$, respectively.

Figure 4 shows the changes in serum sodium and osmolality of patients treated with hypertonic sodium and those treated conservatively. Those treated with hypertonic sodium responded promptly and recovered fully passing between 2.5 and 4.5 litres of urine. Serum sodium concentration was elevated by the end of infusion to $132.5 \mathrm{mmol} / \mathrm{l}( \pm 0.2)$ and had returned to normal level by next morning. No complications or residual signs were observed in this group.

In the conservatively treated group, 2 patients had spontaneously recovered clinically by next morning and biochemically after $48 \mathrm{~h}$. The 2 patients treated with "guarded" volume expansion; they responded to diuretics and each passed 3.5 litres within $4 \mathrm{~h}$ of treatment, one of these patients had cerebral symptoms of lethargy and confusion for $48 \mathrm{~h}$ after surgery, as did another 3 of the conservatively treated patients. The second patient treated with volume expansion was comatose and had leftsided hemiplegia, thought to be a cerebro-vascular accident, on the morning after surgery. He remained fluid overloaded as urine output was followed by further fluid infusions. He recovered after delayed infusion of $5 \% \mathrm{NaCl}$. Comparing the results of the 2 types of treatment, using $\mathrm{X}^{2}$-test, showed statistically significant difference $(\mathrm{P}=0.01)$.

\section{Delayed cerebral signs}

Seven patients, 4 from the conservatively treated group and 3 who had asymptomatic postoperative hyponatraemia with a drop in serum sodium of $>10$ and $<15 \mathrm{mmol} / \mathrm{l}$ were lethargic and confused $21 \mathrm{~h}( \pm 2.5)$ after surgery and remained so for up to $48 \mathrm{~h}$. One patient became comatose and hemiplegic on the first postoperative morning. Serum osmolality of the 7 confused patients was 267 ; in the patients with coma and paralysis it was 250 and in the remaining 92 asymptomatic patients it was $283 \mathrm{mOsm} / \mathrm{l}$. Hypoosmolality was the only significant actor in relation to the delayed cerebral signs $(\mathrm{P}=0.0001)$.

\section{Discussion}

The results of this study have shown that the TURP syndrome is precipitated by sodium-free fluid volumetric overload, the result of glycine absorption and intravenously infused fluids. The measured mean volume of glycine absorption, blood loss and changes of serum electrolytes are similar to those reported by other authors [29-33]. The Data indicate that a volume of $>2$ litres, gained in one hour, can lead to the TURP syndrome; >3.5 litres precipitates VOS1 and multiple system dysfunctions (Figure 2). No patient with the syndrome had a blood loss exceeding 0.4 litres (Table 2); unlike hypovolaemic and septicaemic shock, $5 \% \mathrm{NaCl}$ was shown to be the treatment of choice as further isotonic fluid and blood infusion were contraindicated.

The immediate mean post-operative changes in serum solutes and osmolality (Table 1) were glycine $(+1128 \%)$, glucose $(+73 \%)$, alkaline phosphatise $(-30 \%)$, proteins and albumin $(-15 \%)$, calcium, $\mathrm{Hb}$ and PCV (-10\%), potassium (+4.5\%), sodium $(-4.35 \%)$ and osmolality $(-1.7 \%)$. Our study showed that these changes have previously given rise to individually recognised syndromes and to a hypothesis explaining the TURP syndrome.

Hyponatraemia [4,5] hyponatraemic hypoalbuminasemic syndrome [35], Hypocalcaemia [29], water intoxication and glucose-petrissin syndrome known in obstetrics are examples of syndromes induced by sodium-free fluid volumetric overload (VOS1) which have been attributed to the apparent changes in serum solute concentrations. Also the rise in serum concentration of solutes gained from the absorbed fluid such as glucose, glycine and sorbitol [19] or metabolites presumed to originate from them such as ammonia [27] and oxalates [45] have been incriminated as possible pathogenesis for the TURP syndrome. In the present series, however, neither hypoalbuminaemia, hypocalcaemia nor hyperkalaemia were significant in the pathogenesis of the syndrome.

The results of this study showed that the mean drop in serum osmolality was significant in symptomatic cases, but not overall [11,32]. The changes in serum sodium and glycine were significant in both symptomatic and asymptomatic cases (Table 2). The immediate post-operative serum osmolality gap occurred despite the increase of serum glycine, which does not enter in the formula or calculating osmolality [48]. The half life of glycine has been reported as 85 minutes [48]. This study shows that serum glycine returned to normal within $24 \mathrm{~h}$ and none of the therapeutic measures employed in this study was directly involved in glycine metabolism or clearance.

While the serum chemical and haematological changes were spontaneously returning to normal during the $24 \mathrm{~h}$ post-operative period by endogenous haemostatic correction, serum osmolality continued to fall. Hypo-osmolality proved to be the only significant actor in causing the delayed cerebral signs of the TURP syndrome. 
These findings suggest that hypo-osomotic injury to the brain and other cells of vital and non-vital organs. Desmond [33] observed the relationship between marked hypo-osmolality and the severe cerebral and pulmonary complications of the TURP syndrome. Wright \& Gann [49] proved that induced severe hyponatraemia, without hypo-osmolality, remains asymptomatic.

Osmotic and volume receptors are the main regulators of volumetric overload. Osmotic receptors regulate body water and sodium concentration and protect cells against excessive changes, thus serving to keep body osmolality constant. Volumetric overload, however, causes bradycardia and rarely produces hypertension. The increase in arterial and central venous pressure is transient [11] and affected $2 \%$ of our patients. Hypotension and bradycardia were more consistent signs of volumetric overload. These observations were reported by Logie et al. [22] but they thought bradycardia was inappropriate and the hypotension was attributed to hypovolaemia and blood loss.

The mechanism by which volume overload induces hypotension and shock is not clear. It may be related to a disturbance of capillary circulation which causes heart failure among other system failures. It has been suggested that hypo-albuminaemia lowers the oncotic pressure and so disturbs Starling's forces [50] across the capillary membrane, leading to loss of intravascular fluid and causing interstitial oedema. This has been suggested as explanation of the circulatory shock seen in the TURP syndrome $[11,33]$.

Judging by the post-operative dilution in haemoglobin, PCV, proteins and albumin (mainly intravascular contents), symptomatic patients were in a state of hypervolaemia yet also hypotensive and shocked. This was the most confusing aspect of the pathogenesis of the TURP syndrome in particular and syndromes related to volumetric overload in general.

The paradoxical finding that volumetric overload lowered intravascular pressure, impairing tissue perfusion and causing shock in which hypo-albuminaemia was insignificant, suggested inconsistency with the hypothesis for the capillary-interstitial fluid exchange proposed by Starling [50]. The fact that the capillary is encircled at the inlet by the pre-capillary sphincter inspired the suggestion that it may induce a Venturi effect. Further studies have revealed the totally different roles of the arterial and venous pressures in regulating simulated capillary-interstitial fluid transfer $[43,44]$. In the light of these new findings, future studies are justified in order to explore the effects of volumetric overload on vascular pressures and tissue perfusion, as this may prove relevant to the pathogenesis of multiple organ failure and the adult respiratory distress syndrome. Avoiding further volumetric overload, inducing dieresis and correcting hyponatraemia and hypo-osmolality by hypertonic sodium infusion are effective in treating VOS1 of the TURP syndrome.

\section{Acknowledgement}

We thank Mr J P Ward and Mr K. C. Perry, Consultant Urologists, for including their patients in this study, Dr J. Surtees, Consultant in Chemical Pathology and the laboratory staff at Eastbourne District
General Hospital for their valuable help. Our thanks also go to Dr M. D. Penney, Consultant in Chemical Pathology, Royal Gwent Hospital, Newport for his help and for measuring amino acid concentrations. We are grateful to Professor M. A. Ghoniem, Professor of Urology and Director of the Urology and Nephrology Institute, and the staff at the statistical department, Mansoura University, Egypt, or their generous help and advice.

\section{References}

1. Ghanem AN (1988) The transurethral prostatectomy (TUR) syndrome: an investigation of the osmotic and metabolic sequelae of volumetric overload. Mansoura University, Egypt.

2. Ghanem AN, Ward JP (1990) Osmotic and metabolic sequelae of volumetric overload in relation to the TURP syndrome. Br J Uro 66(1): 71-78.

3. Ghanem AN, Ghanem SA (2016) Volumetric Overload Shocks: Why Is Starling's Law for Capillary Interstitial Fluid Transfer Wrong? The Hydrodynamics of a Porous Orifice Tube as Alternative. Surgical Science 7: 245-249.

4. Harrison III RH, Boren JS, Robinson JR (1956) Dilutional hyponatraemic shock: another concept of the transurethral prostatic reaction. J Uro 75(1): 95-110.

5. Arieff AI (1986) Hyponatraemia, convulsion, respiratory arrest and permanent brain damage after elective surgery in healthy women. $\mathrm{N}$ Engl J Med 314(24): 1529-1534.

6. Ashbaugh DG, Bigelow DB, Petty TL, Levine BE (1967) Acute respiratory distress in adults. Lancet 2(7511): 319-323.

7. Danowski TS, Winkler AW, Elkington JR (1946) The treatment of shock due to salt depression; comparison of isotonic, of hypertonic saline and of isotonic glucose solutions. J Clin Invest 25(1): 130-138.

8. Creevy CD (1947) Haemolytic reactions during transurethral prostatic resection. J Uro 58(2): 125-131.

9. Hagstrom RS (1955) Studies on fluid absorption during transurethral prostatic resection. J Urol 73(5): 852-859.

10. Cathely P, Ramanathan S, Chalon J, rt al. (1981) Decrease in electric thoracic impedence during transurethral resection of the prostate: an index o early water intoxication. J Urol 125(3): 347-349.

11. Sellevold O, Breivic H, Tveter K (1983) Changes in osmotic pressure, osmolality and electrolytes following TURP using glycine as irrigating solution. Scand J Urol Nephrol 17: 31-36.

12. Whisenand JM, Moses JJ (1961) Electrolytes found in the irrigating fluid during transurethral prostatectomy. J Urol 85: 83-84.

13. Colapinto V, Armstrong DJ, Inlayson DC (1973) Red cell mass and plasma volume changes during transurethral prostatic resection. Can J Surg 16(2): 143-151.

14. Henderson DJ, Middleton RG (1980) Coma from hyponatraemia of the transurethral resection of prostate. Urology 15(3): 267-271.

15. Istre O, Bjoennes J, Naes R, Hornbaek K, Forman A (1994) Postoperative cerebral oedema after Transcervical Endometrial Resection and Uterine Irrigation with 1.5\% Glycine. Lancet 344(8931): 1187-1189.

16. Ayus JC, Krothapalli RK, Arieff AI (1987) Treatment o symptomatic hyponatraemia and its relation to brain damage. New Engl J Med 317: 1190-1195.

17. Arieff AI, Ayus JC (1993) Endometrial ablation complicated by fatal hyponatraemic encephalopathy. JAMA 270(10): 1230-1232.

18. Jacobson J (1965) Prolonged respiratory inadequacy following Transurethral Resection of the Prostate. Anaesth. 1965; 20: 329-333.

19. Allen PR, Hughes RG, Goddie DJ, et al. (1981) Fluid absorption during TUR. Br Med J 282: 740.

20. Charlton AJ (1980) Cardiac arrest during transurethral surgery after absorption of $1.5 \%$ glycine. Anaesth. 35: 804-807. 
21. Evans JWH, Singer M, Chapple CR, Macartney N, Walker JM, et al (1992) Haemodynamic evidence for cardiac stress during transurethral surgery.Br Med Jour 304(6828): 666-671.

22. Logie JRC, Keenan RA, Whiting PH, et al. (1980) Fluid absorption during prostatectomy. Br J Urol 52(6): 526-528.

23. Bertrand J, Gambini A, Cazalaa JB, et al. (1981) Le syndrome de resection de la prostate (TURP) syndrome, mythe oy realite? Jour d' Urologie 87: $1-4$.

24. Norris HT, Aashem GM, Sherrard DJ, Tremann JA (1973) Symptomatology, pathophysiology and treatment of the transurethral resection of the prostate. Br J Urol 45: 420-427.

25. Lessels AM, Honan RP, Haboubi NY, Ali HH, Greene MJ (1982) Death during prostatectomy. J Clin Path 35: 117.

26. Kay MC, Kay J, Begun F, Yeung JE (1985) Vision loss following transurethral resection of the prostate. J Clin Neuroophthalmol 5(4): 273-276

27. Hoekstra Pt, Kahnoski R, McCamish MA, Bergen W, Heetderks DR (1983) Transurethral prostatic resection syndrome- a new perspective: Encephalopathy with associated hyperammonaemia. J Uro 130(4): 704707.

28. Kirshenbaum MA (1979) Sever mannitol induced hyponatraemia complicating transurethral prostatic resection. J Uro 121(5): 686-688.

29. Rhymer JC, Bell TJ, Perry KC, Ward JP (1985) Hyponatraeia following transurethral resection of the prostate. Br J Urol 57 (4): 450-452.

30. Rao PN (1987) Fluid absorption during urological endoscopy. Br J Urol 60(2): 93-99.

31. Beirne GN, Madsen PO, Burns RO (1965) Serum electrolyte and osmolality changes following transurethral resection of the prostate. $\mathrm{Br}$ Jour Uro 93: 83-86.

32. Berg G, Fedor EJ, Fisher B (1962) Physiologic observations related to the transurethral resection reaction. J Uro 87(4): 596-600.

33. Desmond J (1970) Serum osmolality and plasma electrolytes in patients who develop dilutional hyponatraemia during transurethral resection. Can Jour Surg 13(2): 116-121.

34. Bird D, Slade N, Feneley RCL (1982) Intravascular complication of transurethral prostatectomy. Br J Uro 54: 564-565.

35. Dandonna P, Fonseca V, Baron D (1985) Hypoalbuminimic hyponatraemia: a new syndrome? Br Med. J., 291, 1253-1255.

36. Ekengreen J, Hahn R (1993) Blood loss during transurethral resection of the prostate as measured by the Hemocue photometer. Scand J Uro Nephrol 27(4): 501-507.
37. Friedman NJ, Hoag MS, Robinson AJ, Aggeler PM (1969) Haemorrhagic syndromes following transurethral resection for benign adenoma. Arch Intern Med 124(3): 341-349.

38. Hahn RG (1990) Fluid and electrolyte dynamics during development of the TURP syndrome. Br J Urol 66(1): 79-84.

39. Hahn GH, Zhang W, Rajs J (1996) Pathology of the heart after overhydration with glycine solution in the mouse. APMIS 104: 915-920.

40. Hahn RG, Nennesmo I, Rajs J, Sundelin B, Wróblewski R, et al. (1996) Morphological and X-ray Micro-analytical Changes in Mammalian Tissue after Overhydration with Irrigating Fluids. Eur Uro 29(3): 355361.

41. Hahn RG, Nilsson H, Carlstrom H, Hjelmqvist H, Zhang W, et al. (1996) Renal function during intravenous infusion of urological irrigating fluids in the sheep. Acta Anaesthesiol Scand 40(6): 671-678.

42. GSwales JD (1987) Dangers in treating hyponatraemia. Br Med J (Clin Res Ed) 294(6567): 261-262.

43. Ghanem AN (2001) Magnetic field-like fluid circulation of a porous orifice tube and its relevance to the capillary-interstitial fluid circulation: preliminary report. Med Hypotheses 56(3): 325-334.

44. Ghanem KA, Ghanem AN (2017) The proof and reasons that Starling's law for the capillary-interstitial fluid transfer is wrong, advancing the hydrodynamics of a porous orifice $(\mathrm{G})$ tube as the real mechanism. Blood, Heart and Circ (1): 1-7

45. Malone PR, Davies JH, Standield NU, etal. (1986) Metabolic consequences of forced dieresis following prostatectomy. Br J Urol 58: 406-411.

46. Guyton AC, Colman TG (1968) Regulation of interstitial fluid volume and pressure. Ann N Y Acad Sci 150: 537-547.

47. Norlen H, Allgen LG, Vinnars E, et al. (1986) Glycine solution as an irrigating solution during transurethral prostatic resection. Scand J Urol Neph 20(1): 19-26.

48. Worthley LIG, Guerin M, Pain RW (1987) For calculating osmolality the simple formula is the best. Anaesth Intensive Care 15(2): 199-202.

49. Wright HK, Gann DS (1962) Severe postoperative hyponatraemia without symptoms of water intoxication. Surg Gynecol Obstet 115: 553556.

50. Starling EH (1886) Factors involved in the causation of dropsy. Lancet. 